\title{
A Note on Style
}

The church founded by Joseph Smith in 1830 was called the Church of Christ. In 1834 the name changed to the Church of the Latter Day Saints. Then, in 1838, the church adopted the name the Church of Jesus Christ of Latter-day Saints. While this has remained the church's official name since 1838, throughout its history the church has been alternately referred to as the Mormon Church or the LDS Church. The term "Mormon" has also been used to refer to other individuals, institutions, and practices that trace their origins to Joseph Smith. In this book we use the official name of the church as the first reference in each chapter and use "the church" as a shortened reference thereafter. When referring to church members, we use "Latter-day Saints," "Saints," and "Mormons" interchangeably. We also use "Mormon" or "Mormons" in proper nouns, historical context, and quotations from historical sources. 

CONTINGENT CITIZENS 
